\title{
Penerapan Model Pertanian Ramah Lingkungan sebagai Jaminan Perbaikan Kuantitas dan Kualitas Hasil Tanaman Pangan
}

\author{
Application of Environmental Friendly Agriculture Models as \\ Guaranttee in Improving Quantity and Quality of Rice Yields
}

\author{
Anicetus Wihardjaka \\ Balai Penelitian Lingkungan Pertanian \\ Jl. Jakenan-Jaken km 5 Jakenan Pati 59182 Jawa Tengah \\ Email : awihardjaka@yahoo.co.id
}

Diterima : 13 Juli 2018

Revisi : 2 Agustus 2018

Disetujui : 12 September 2018

\begin{abstract}
ABSTRAK
Keberhasilan peningkatan produktivitas tanaman pangan yang diikuti dengan kelestarian lingkungan hidup merupakan prinsip penerapan sistem pertanian ramah lingkungan berkelanjutan. Berbagai sistem pertanian ramah lingkungan telah dikembangkan dengan berpedoman pada budidaya pertanian yang baik melalui sinergis antar komponen teknologi, antara lain pengelolaan tanaman terpadu, jajar legowo super, sistem integrasi tanaman-ternak bebas limbah, dan pengendalian organisme pengganggu tanaman secara terpadu. Melalui sinergi komponen teknologi secara terpadu, penerapan sistem pertanian ramah lingkungan memantapkan capaian produktivitas tanaman pangan, kualitas tanah terpelihara, dan emisi gas rumah kaca dapat tereduksi. Beberapa komponen teknologi yang mampu memberikan hasil tanaman tinggi, emisi gas rumah kaca rendah, dan rendah kontaminan antara lain pengairan berselang, penggunaan bahan organik matang (nisbah $\mathrm{C} / \mathrm{N}$ rendah) dengan bantuan biodekomposer, pemupukan berimbang, pengendalian hama secara terpadu dengan mengandalkan pestisida nabati, jarak tanam legowo, dan varietas padi unggul rendah emisi. Melalui pengelolaan tanaman terpadu, hasil padi sawah dapat meningkat hingga 47 persen, pendapatan petani meningkat 29-76 persen, dan emisi GRK turun sekitar 18-26 persen.
\end{abstract}

kata kunci: produktivitas, tanaman pangan, ramah lingkungan, bebas limbah, terpadu

\section{ABSTRACT}

The successful increase of food crops productivity that followed by environmental sustainability is a principle of environmentally-friendly and sustainable agriculture. Various environmentally friendly agriculture systems have been developed based on good agricultural practices which are synergic among technological components, e.g., integrated crops management, superior wide-spacing rows systems, integrated crops-livestock with zero wastes, and integrated pest management. Application of environmentally friendly agriculture through synergic integrated technological components could increase food crops productivity, maintain soil quality, and reduce greenhouse gas emissions. Some technological components that could give high grain yield, low greenhouse gas emissions, and low contaminants are intermittent irrigation, fermented organic matter application using bio-decomposer (low $\mathrm{C} / \mathrm{N}$ ratio), balanced fertilization, integrated pest management with priority of botanical pesticides use, crops spacing of legowo, and use of high-yielding variety with low emission. Through applying integrated crop management, rice yield could increase to 47 percent, farmer income increases as much as 29-76 percent, and greenhouse gas emissions decrease about 18-26 percent.

key words: productivity, food crops, environmentally friendly, zero waste, integrated

Penerapan Model Pertanian Ramah Lingkungan sebagai Jaminan Perbaikan Kuantitas dan Kualitas Hasil 


\section{PENDAHULUAN}

S alah satu program prioritas Kementerian Pertanian dalam mengimplementasikan

Nawacita Presiden Joko Widodo - Wakil Presiden Jusuf Kalla adalah kedaulatan pangan, melalui pencapaian swasembada dan peningkatan produktivitas komoditas padi, jagung, kedelai, cabai, bawang merah, daging dan gula. Upaya pencapaian tersebut dilakukan melalui berbagai kegiatan seperti upaya khusus, intensifikasi dan ekstensifikasi pertanian baik melalui peningkatan indeks pertanaman (IP) maupun perluasan luas baku sawah untuk mewujudkan kemandirian pangan. Sasaran produksi komoditas pangan terutama padi, jagung, dan kedelai pada 2015-2019 adalah peningkatan produksi padi dari 73.162.171 ton (2014) menjadi 81.971.853 ton (2019), jagung dari 20.087.445 ton (2014) menjadi 22.506.235 ton (2019), dan kedelai dari 1.265.646 ton (2014) menjadi 1.418.046 ton (2019) (Kementerian

Pertanian, 2015).

Pembangunan pertanian dihadapkan pada berbagai tantangan, antara lain: perubahan iklim yang mengancam kerawanan pangan, konversi areal budidaya menjadi non pertanian, pertumbuhan penduduk yang sejalan dengan peningkatan kebutuhan bahan pangan, eksploitasi dan degradasi sumberdaya lahan pertanian yang menurunkan kualitas tanah, lingkungan dan produk pertanian. Undang-Undang No 18 tahun 2012 tentang pangan mengamanatkan bahwa selain ketahanan dan kemandirian pangan, keamanan pangan perlu diperhatikan. Peningkatan produktivitas tanaman pangan hendaknya juga diimbangi dengan peningkatan kualitas tanah dan produk pertanian. Dalam mencapai sasaran tersebut, budidaya tanaman pertanian, khususnya tanaman pangan dilakukan dengan pendekatan budidaya pertanian yang baik (good agricultural practices/GAP) yang tidak lain adalah sistem pertanian ramah lingkungan.

Tujuan tulisan ini adalah untuk memberikan informasi bahwa penerapan pertanian ramah lingkungan berpengaruh nyata terhadap perbaikan kuantitas dan kualitas hasil tanaman pangan.

\section{PERTANIAN LINGKUNGAN}

RAMAH

Pertanian ramah lingkungan merupakan sistem pertanian berkelanjutan yang bertujuan untuk meningkatkan dan mempertahanan produktivitas tinggi dengan memperhatikan pasokan hara dari penggunaan bahan organik, minimalisasi ketergantungan pada pupuk anorganik, perbaikan biota tanah, pengendalian organisme pengganggu tanaman (OPT) berdasarkan kondisi ekologi, dan diversifikasi tanaman (Hendrawati, 2001). Soemarno (2001) mendefinisikan pertanian ramah lingkungan sebagai pertanian yang menerapkan teknologi serasi dengan lingkungan untuk optimasi pemanfaatan sumberdaya alam dalam memperoleh produksi tinggi dan aman, serta menjaga kelestarian lingkungan dan sumberdaya alam pertanian. Berdasarkan definisi tersebut, pembangunan pertanian diarahkan pada pencapaian ketahanan pangan sekaligus juga memperhatikan keamanan pangan. Konsep pertanian ramah lingkungan tersebut bermuara pada kualitas tanah yang mempengaruhi : (i) produktivitas tanah untuk meningkatkan produktivitas tanaman dan aspek hayati lainnya; (ii) memperbaiki kualitas lingkungan dalam menetralisasi kontaminan-kontaminan dalam tanah dan produk pertanian; dan (iii) kesehatan manusia yang mengkonsumsi produk pertanian (Doran dan Parkin, 1999).

Pengembangan pertanian ramah lingkungan terutama untuk tanaman pangan dan hortikultura harus memperhatikan beberapa hal, antara lain: (i) menjaga keragaman hayati dan keseimbangan ekologis biota alami; (ii) memelihara kualitas fisik, kimiawi, hayati sumberdaya lahan pertanian; (iii) meminimalisasi kontaminan residu bahan agrokimia, limbah organik dan anorganik yang berasal dari dalam ataupun luar usaha tani; (iv) mempertahankan produktivitas lahan secara alami; (v) patogen penyakit dan serangan hama tidak terakumulasi secara endemik dan terjaganya musuh alami; dan (vi) produk pertanian aman sebagai bahan pangan dan pakan (Soemarno, 2001).

Sistem pertanian ramah lingkungan sebenarnya telah banyak diterapkan oleh

Penerapan Model Pertanian Ramah Lingkungan sebagai Jaminan Perbaikan Kuantitas dan Kualitas Hasil Tanaman Pangan 
masyarakat tani, antara lain pertanian konservasi dengan tanpa olah atau olah tanah minimum, pengelolaan tanaman terpadu, penerapan jajar legowo super, pengelolaan organisme pengganggu tanaman secara terpadu, sistem integrasi tanaman-ternak bebas limbah, dan pertanian organik. Menurut Soemarno (2001), tindakan operasional pertanian ramah lingkungan meliputi: (i) Penggunaan pupuk anorganik bersifat suplementatif dengan efisiensi tinggi untuk mencapai target hasil optimal; (ii) penerapan pengendalian hama dan penyakit dengan memperhatikan keseimbangan ekologis alamiah; (iii) penerapan pengelolaan tanaman secara terpadu; (iv) penerapan sistem usaha tani bersih dan sehat; (v) pemeliharaan dan pemantapan kesuburan fisik, kimiawi, dan hayati secara alamiah, dan (vi) pemanfaatan teknologi efektif berdasar kearifan lokal.

\section{PENGELOLAAN TERPADU}

Pengelolaan tanaman terpadu (PTT) merupakan salah satu model pertanian ramah lingkungan yang mengintegrasikan berbagai komponen teknologi untuk meningkatkan produktivitas tanaman tanpa merusak lingkungan. Sejak tahun 2015, Pemerintah menggalakkan gerakan penerapan pengelolaan tanaman terpadu (GP-PTT) untuk mengungkit produktivitas komoditas pangan strategis seperti padi, jagung, dan kedelai. Pengembangan PTT bersifat spesifik lokasi dilakukan dan digalakkan dengan sekolah lapang pengelolaan tanaman terpadu (SL-PTT) dan dilanjutkan dengan GP-PTT yang dikemas ke dalam upaya khusus (Upsus) untuk mewujudkan kedaulatan pangan. Tahun 2014, pengembangan PTT melalui SL-PTT adalah 80,74 persen dari luasan 4.625.000 hektar SL-PTT (Ditjen Tanaman Pangan, 2014).

Pendekatan inovatif peningkatan produktivitas dan efisiensi usaha tani melalui PTT bersifat spesifik lokasi dengan melibatkan partisipasi petani terhadap sinergi antar komponen teknologi (Ditjen Tanaman Pangan, 2014). Menurut Balitbangtan (2007), prinsip penerapan PTT adalah: (i) PTT merupakan pendekatan melalui pengelolaan sumberdaya tanaman, lahan, dan air; (ii) PTT memanfaatkan teknologi pertanian yang telah berkembang dan diterapkan dengan memperhatikan sinergi antar teknologi; (iii) PTT memperhatikan kesesuaian teknologi dengan lingkungan fisik, sosial-ekonomi petani; dan (iv) PTT bersifat partisipatif melibatkan peran aktif petani dalam memilih teknologi yang sesuai dengan kondisi setempat.

Sekilas PTT mirip dengan SRI (Sistem
padi intensifikasi), tetapi PTT lebih menekankan sinergis antar komponen teknologi. Komponen teknologi dalam PTT mengungkit produktivitas tanaman sekaligus berkontribusi terhadap penurunan emisi gas rumah kaca sebagai penyebab pemanasan global dan perubahan iklim, serta mengantisipasi terjadinya residu bahan agrokimia dalam tanah dan produk pertanian. Menurut Abdulrachman (2011), komponen teknologi yang diintroduksikan dalam PTT meliputi :(i) Varietas unggul baru yang sesuai dengan karakteristik lahan, lingkungan, dan keinginan petani; (ii) Benih bermutu baik kemurnian maupun daya kecambah tinggi; (iii) Bibit muda $(<21$ hari setelah sebar); (iv) Jumlah bibit 1-3 batang per lubang dan sistem tanam jajar legowo $2: 1,4: 1$ dan lainnya dengan populasi minimum 250.000 rumpun/ha; (v) Pemupukan $\mathrm{N}$ berdasarkan bagan warna daun (BWD); (vi) Pemupukan $\mathrm{P}$ dan $\mathrm{K}$ berdasarkan status hara tanah, PUTS atau petak omisi; (vii) Bahan organik (kompos jerami 5 ton/ha atau pupuk kandang 2 ton/ha); (viii) Pengairan berselang (intermittent irrigation); (ix) Pengendalian secara terpadu organisme pengganggu tanaman (gulma, hama, penyakit tanaman); dan $(x)$ Panen dan pasca panen menggunakan alat mesin pertanian ditjen(alsintan). Keberadaan sekolah lapang pengelolaan tanaman terpadu mampu meningkatkan produktivitas padi sawah berkisar 34-47 persen dan pendapatan petani sebesar 29-76 persen dibandingkan non SL-PTT (Asnawi, 2014).

Dibandingkan rezim air pengairan
terus menerus, pengairan berselang
(intermittent irrigation) memberikan hasi
gabah tidak berbeda nyata. Pengairan
berselang menghasilkan emisi gas rumah
kaca metana nyata lebih rendah daripada


pengairan terus menerus (Tabel 1 ), selain menghemat kebutuhan air. Pengelolaan tanaman terpadu mampu menurunkan emisi metana berkisar 18-26 persen. kendali; dan (v) alat mesin pertanian terutama untuk tanam dan panen (Balitbangtan, 2016). Teknologi jajar legowo super bersifat spesifik lokasi seperti

Tabel 1. Hasil Gabah dan Emisi Metana pada Rejim Air berbeda di Kabupaten Pati, Jawa Tengah

\begin{tabular}{lcc}
\hline Rejim air & $\begin{array}{c}\text { Hasil gabah kering } \\
\text { giling (ton/ha) }\end{array}$ & $\begin{array}{c}\text { Emisi metana } \\
\left(\mathrm{kg} \mathrm{CH}_{4} / \mathrm{ha} / \mathrm{musim}\right)\end{array}$ \\
\hline Non PTT - irigasi terus & $6,72 \pm 0,19$ & $283 \pm 36$ \\
menerus & $6,49 \pm 1,15$ & $58 \pm 7$ \\
Non PTT - irigasi berselang & $7,10 \pm 0,08$ & $347 \pm 82$ \\
PTT - irigasi terus menerus & $6,76 \pm 0,14$ & $78 \pm 42$ \\
PTT - irigasi berselang &
\end{tabular}

Sumber: Setyanto dan Kartikawati (2008)

\section{JAJAR LEGOWO SUPER}

Jajar legowo super merupakan sistem pertanian ramah lingkungan yang menerapkan teknologi budidaya tanaman pangan terutama padi secara terpadu berbasiskan jarak tanam jajar legowo. Penerapan sistem tanam jajar legowo 2:1 dengan jarak tanam $25 \mathrm{~cm}$ x $12,5 \mathrm{~cm} \times 50$ $\mathrm{cm}$ meningkatkan populasi tanaman menjadi 213.333 rumpun/ha atau meningkat 33,3 persen dibandingkan dengan sistem tanam tegel $25 \mathrm{~cm} \times 25 \mathrm{~cm}$ dengan populasi 160.000 rumpun per ha (Balitbangtan, 2016). Dalam implementasinya, komponen teknologi jarwo super terdiri atas : (i) benih bermutu varietas unggul baru (VUB) dengan potensi hasil tinggi; (ii) biodekomposer pada saat pengolahan tanah; (iii) pupuk hayati sebagai seed treatment dan pemupukan berimbang; (iv) teknik pengendalian organisme pengganggu tanaman (OPT) secara terpadu yang menggunakan pestisida nabati atau agensia hayati atau pestisida anorganik berdasarkan ambang agroekosistem sawah optimal, sawah tadah hujan, lahan kering beriklim kering, dan sawah pasang surut. Tahun 2016, teknologi jajar legowo super dikembangkan ke 11 provinsi pada lahan seluas total 300 hektar (Republika, 2016). Sinar Tani (2017), melaporkan bahwa varietas padi Inpari 33 yang dibudidayakan dengan sistem jarwo super mampu menghasilkan gabah 8,5 ton kering panen tiap hektarnya.

Salah satu pupuk hayati hasil inovasi Badan Penelitian dan Pengembangan Pertanian (Balitbangtan) adalah Agrimeth. Pupuk hayati ini mengandung berbagai mikroba bermanfaat seperti bakteri penambat $\mathrm{N}_{2}$ baik secara simbiotik maupun non simbiotik, bakteri pelarut fosfat, dan bakteri penghasil fitohormon. Pupuk hayati Agrimeth mampu meningkatkan efisiensi pupuk anorganik N P K dan meningkatkan produktivitas tanaman pangan seperti padi dan kedelai (Balitbangtan, 2016).

Biodekomposer dapat digunakan dalam pembuatan kompos jerami.

Tabel 2. Hasil Gabah dan Emisi Metana di Ekosistem Sawah Tadah Hujan yang diberi Jerami Segar dan Kompos Jerami

\begin{tabular}{lcccc}
\hline \multirow{2}{*}{$\begin{array}{l}\text { Pemberian } \\
\text { jerami padi }\end{array}$} & \multicolumn{2}{c}{ Hasil gabah kering giling (t/ha) } & \multicolumn{2}{c}{$\begin{array}{c}\text { Emisi metana }(\mathrm{kg} \\
\left.\mathrm{CH}_{4} / \mathrm{ha} / \mathrm{musim}\right)\end{array}$} \\
\cline { 2 - 5 } & Tanam pindah & $\begin{array}{c}\text { Tanam benih } \\
\text { langsung }\end{array}$ & $\begin{array}{c}\text { Tanam pindah } \\
\text { Tanam benih } \\
\text { langsung }\end{array}$ \\
\hline Tanpa jerami & 3,93 & 6,94 & 97 & 76 \\
Jerami segar & 4,24 & 7,21 & 144 & 98 \\
Kompos & 4,20 & 7,64 & 127 & 72 \\
jerami & & & & \\
\hline
\end{tabular}

Sumber: Wihardiaka (2011)

Penerapan Model Pertanian Ramah Lingkungan sebagai Jaminan Perbaikan Kuantitas dan Kualitas Hasil 
Pembenaman kompos jerami ke dalam saat pengolahan tanah cenderung memberikan hasil gabah padi sawah tadah hujan dengan varietas Ciherang lebih tinggi daripada pengembalian jerami segar. Selain itu pemberian kompos jerami yang bernisbah $\mathrm{C} / \mathrm{N}$ rendah memberikan emisi metana $\left(\mathrm{CH}_{4}\right)$ lebih rendah daripada jerami segar (Tabel 2). Penggunaan biodekomoser secara tidak langsung memberikan kontribusi nyata terhadap stabilitas produksi padi tinggi sekaligus sebagai upaya mitigasi emisi gas rumah kaca dari subsektor tanaman pangan. Kompos jerami yang diinokulasi dengan Azospirillum meningkatkan hasil gabah kering padi sawah 30 persen (setara 1,40 ton/ha) dan menghemat penggunaan pupuk nitrogen sebesar 45 kg N/ha (Gunarto, dkk., 2002)

\section{SISTEM INTEGRASI TANAMAN TERNAK BEBAS LIMBAH}

Penerapan sistem integrasi tanamanternak merupakan sistem pertanian ramah iklim sebagai antisipasi dampak perubahan iklim yang mensinergiskan teknologi adaptasi dan teknologi mitigasi emisi gas rumah kaca. Komponen utama dalam sistem ini adalah budidaya tanaman pangan ramah lingkungan, pengelolaan ternak, dan perbaikan kualitas tanah dan lingkungan. Balai Penelitian Lingkungan Pertanian telah mengembangkan SITT bebas limbah yang dijelaskan pada Gambar 1.

Dalam sistem ini, varietas padi unggul rendah emisi gas rumah kaca digunakan dan ditanam dengan sistem tanam jajar legowo 2:1. Beberapa varietas unggul berdaya emisi rendah antara lain adalah Ciherang, Mekongga, Memberamo, Way Apoburu, Situ Bagendit, Inpari 13, dan Inpari 24. Menurut Setyanto (2006), indeks emisi atau nisbah hasil padi terhadap fluk metana digunakan untuk menghitung jumlah metana yang dilepaskan dari varietas padi. Makin tinggi indeks emisi suatu varietas, varietas tersebut relatif mengemisi metana rendah, misal Indeks emisi dari Way Apoburu dan Tukad Unda yang masingmasing 48,1 dan 28,6 kg gabah/ $\mathrm{kg} \mathrm{CH}_{4}$, berarti varietas Way Apoburu melepaskan metana lebih rendah daripada Tukad Unda. Komponen teknologi lainnya berupa pemupukan berimbang dimana pemberian pupuk anorganik berdasarkan hasil uji tanah dan bagan warna daun (BWD). Sistem pengairan menerapkan irigasi berselang (intermittent) sesuai kebutuhan tanaman dan kondisi di lapangan. Penerapan pengairan berselang nyata menurunkan emisi gas rumah kaca tanpa mengurangi hasil tanaman.

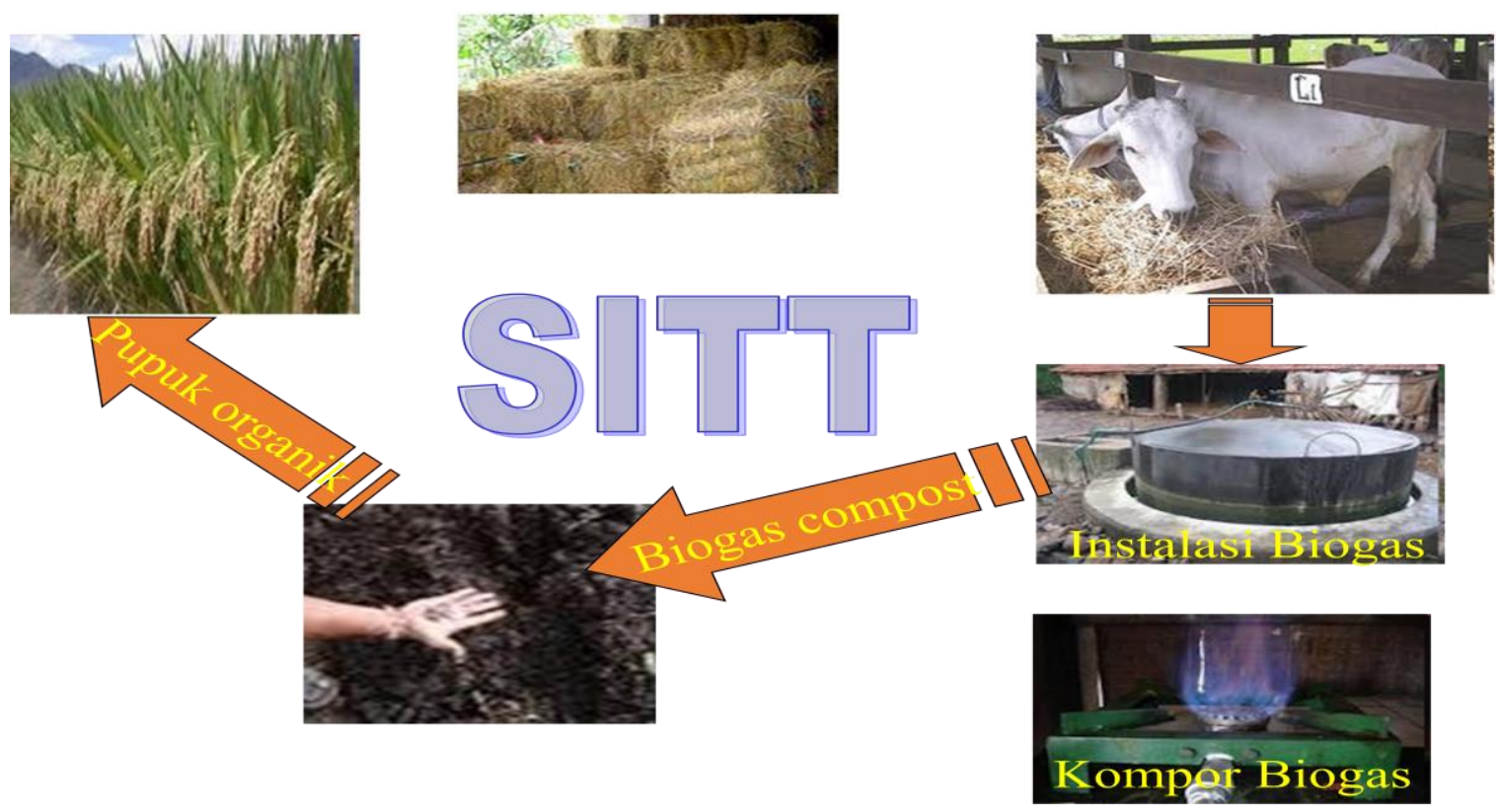

Gambar 1. Sistem Integrasi Tanaman Padi-Ternak Sapi di Instalasi Kebun Percobaan Jakenan, Pati, Jawa Tenqah (Sumber: Wihardiaka, dkk., 2013) 
Bahan organik pada sistem ini dikembalikan ke dalam tanah untuk memperbaiki kesuburan fisik, kimia dan hayati tanah, yaitu jerami yang dikomposkan, kompos kotoran ternak, limbah pasca biodigester berupa padatan (sludge) maupun cairan (slurry), dan kombinasi kompos kotoran sapi + arang hayati. Energi terbarukan berupa metana dari biodigester dimanfaatkan untuk kebutuhan harian rumah tangga dan sebagai energi dalam proses pirolisis pembuatan arang hayati dari limbah pertanian yang berlignin tinggi. Kompos kotoran sapi yang dihasilkan dari biodigester mampu menurunkan emisi metana dari tanaman padi sebesar 59,1 persen dibandingkan jerami segar yang langsung dibenamkan ke dalam tanah sawah (Wihardjaka, dkk., 2013)

Hasil biomassa berupa jerami padi digunakan sebagai pakan ternak dan sebagian dikomposkan untuk dikembalikan ke dalam tanah. Sebagai pakan ternak, kualitas jerami perlu ditingkatkan melalui fermentasi dengan probiotik starbio untuk menurunkan kadar fraksi serat kasar (NDF, NDS, ADF, dan hemiselulosa) (Sembiring dan Kusdiaman, 2008). Perbaikan kualitas pakan dari jerami nyata menurunkan produksi metana dari fermentasi enterik ternak ruminansia.

Proses dekomposisi jerami dipercepat dengan menggunakan biodekomposer yang mengandung mikroba perombak bahan organik. Kompos jerami dapat mengurangi biaya kebutuhan pupuk $\mathrm{KCl}$. Arang hayati (biochar) dapat digunakan sebagai pelapis pupuk urea untuk meningkatkan efisiensi penggunaan pupuk nitrogen, sebagai pengikat kontaminan residu bahan agrokimia, dan sebagai bahan filter saluran irigasi.

\section{PENGENDALIAN OPT TERPADU}

Serangan organisme pengganggu tanaman (OPT) seperti gulma, hama, dan penyakit tanaman merupakan kendala dan tantangan dalam memantapkan hasil budidaya tanaman pertanian yang tinggi atau memperkecil kehilangan hasil. Keberadaan gulma mampu menurunkan hasil berkisar 18-68 persen (Humaedah, 2017). Menurut Rola dan Pingali (1993), serangan hama nyata meningkatkan kehilangan hasil tanaman budidaya, misal serangan penggerek batang mampu mengakibatkan kehilangan hasil padi berkisar 20-95 persen di beberapa negara Asia Tenggara dan Selatan. Sejak era revolusi hijau pada tahun 1970-an, penggunaan pestisida sintetis meningkat nyata dan berpengaruh terhadap keberhasilan capaian produksi tanaman tinggi. Namun kecenderungan petani menggunakan pestisida sintetis secara tidak bijaksana meningkatkan akumulasi residu dalam tanah, air, produk pertanian, menyebabkan resurjensi, predator dan musuh alami hama terbunuh, dan mengganggu kesehatan manusia (Soejitno, 2002).

Residu pestisida yang terdeteksi dalam tanah dan produk pertanian telah banyak dilaporkan, antara lain: Indraningsih, dkk. dalam Harsanti, dkk. (2009) melaporkan residu pestisida organoklorin (DDT, heptaklor, lindan) dalam padi, jagung, kedelai, tomat; Indratin, dkk. (2009) melaporkan residu beberapa senyawa organoklorin terdeteksi dalam darah petani sayuran di Jawa Tengah (Pati, Magelang, Brebes) dengan kisaran konsentrasi td-0,77 mg/kg lindan; 0,02-0,13 $\mathrm{mg} / \mathrm{kg}$ aldrin; td-0,05 mg/kg heptaklor; dan td-0,15 $\mathrm{mg} / \mathrm{kg}$ endosulfan; Kurnia, dkk. (2009) melaporkan bahwa residu organofosfat terutama klorpirifos dan diazinon dalam tanah sawah di Jawa Tengah telah melebihi nilai acceptable daily intake/ADI $(0,01 \mathrm{mg} / \mathrm{kg}$ untuk klorpirifos dan $0,002 \mathrm{mg} / \mathrm{kg}$ untuk diazinon); Sulaeman dan Ardiwinata (2009) melaporkan bahwa residu organoklorin DDT dan aldrin di tanah dan air sawah di Jawa Barat telah melebihi nilai ADI.

Pendekatan pengendalian OPT terpadu diarahkan sebagai upaya pengendalian yang ramah lingkungan. Konsep HPT awal adalah pengendalian hama yang memadukan pengendalian hayati dengan pengendalian kimiawi untuk membatasi penggunaan pestisida (Stern dkk. dalam Untung, 2000). Menurut Bottrell dalam Untung (2000), PHT menekankan pada pemilihan, perpaduan dan penerapan pengendalian hama yang didasarkan pada perhitungan dan penaksiran konsekuensi- 
konsekuensi ekonomi, ekologi, dan sosiologi. Pelatihan petani tentang konsep PHT telah dilakukan bahkan hingga tahun 1999 tercatat lebih dari satu juta petani padi dan hortikultura telah mengikuti program pelatihan PHT selama satu musim dalam forum sekolah lapangan pengendalian hama terpadu (SL-PHT) (Untung, 2000).

Konsep PHT di Indonesia, selain seb agai teknik pengendalian hama, tetapi juga sebagai pendekatan pemberdayaan dan peningkatan kualitas sumberdaya manusia dan menempatkan petani sebagai penentu dan pelaksana utama PHT di tingkat lapangan (Untung, 2000). Menurut Rola dan Pingali (1993), ketergantungan terhadap pestisida sintetis dalam konsep PHT dikurangi dengan menggunakan varietas tahan, bio-kontrol dengan agensia hayati seperti Bacillus thuringiensis, atau penggunaan pestisida botani/nabati. Beberapa varietas padi yang relatif tahan terhadap wereng coklat biotipe 1, 2, 3

Tabel 3. Tumbuhan yang Berpotensi sebagai Pestisida Nabati di Indonesia (Sumber: Ditjen Bina Perlindungan Tanaman Perkebunan dalam Fagi, dkk., 2013)

\begin{tabular}{|c|c|c|c|}
\hline Nama lokal & Nama latin & Nama lokal & Nama latin \\
\hline $\begin{array}{l}\text { Saliara, } \\
\text { Jawerkotok }\end{array}$ & Lantana camara & Tembakau & Nicotiana tabacum \\
\hline Mindi & Melia azedarach & Gadung & Dioscorea hispida \\
\hline Lidah buaya & Agave americana & Paitan & $\begin{array}{l}\text { Eupatorium } \\
\text { inulifolium }\end{array}$ \\
\hline Jambu mete & $\begin{array}{l}\text { Anacardium } \\
\text { occidentale }\end{array}$ & Kenikir & Tagetes patula \\
\hline Sirsak & Annona muricata & Temu ireng & $\begin{array}{l}\text { Curcuma longa, } \\
\text { Curcuma } \\
\text { aeruginosa }\end{array}$ \\
\hline Srikaya & Annona squamosa & Kencur & Kaemferia galnaga \\
\hline Iles-iles (acung) & $\begin{array}{l}\text { Amophophallus } \\
\text { campanulatus }\end{array}$ & Rengas & Gluta rengkas \\
\hline Manggis negri & Mammea americana & Bintaro & $\begin{array}{l}\text { Cerbera mangkas, } \\
\text { Cerbera lakataria }\end{array}$ \\
\hline Cibreng & Gliricidea sepium & Ginje & $\begin{array}{l}\text { Theretia } \\
\text { penefianum }\end{array}$ \\
\hline Seureuh / sirih & Piper betle & Tikel balung & Euphorbia tirucalla \\
\hline Kacang babi & Teprosia vogelli & Ubi kayu & Manihot esculenta \\
\hline $\begin{array}{l}\text { Tuwaleteng } \\
\text { laleiur }\end{array}$ & Derris elliptica & Kliwak & Pangium edule \\
\hline Laban, legundi & Vitex negundo & Keben & $\begin{array}{l}\text { Barngtonia } \\
\text { asiatica }\end{array}$ \\
\hline Ujung pandan & Rhus coriaria & $\begin{array}{l}\text { Bengkuang, } \\
\text { Besusu }\end{array}$ & $\begin{array}{l}\text { Pachyrhizus } \\
\text { erosus }\end{array}$ \\
\hline Kipahit & Tithonia tagritifolia & Mandalika & Gloriosa superba \\
\hline Mimba & Azadiracha indica & Oyod peron & Anamirta coccolug \\
\hline Babakoan & Calotropis gigantea & Ancar karang & Antiaris toxicarin \\
\hline Jarak & Sapindus marginatus & Jambu & Areca catechu \\
\hline Piretrum & $\begin{array}{l}\text { Crysanthemum } \\
\text { cinerariaefolium }\end{array}$ & Sawo kecik & $\begin{array}{l}\text { Plygomun } \\
\text { barbatum }\end{array}$ \\
\hline Kipahang laut & Pongumia glabra & Toweran & Derris barbatum \\
\hline $\begin{array}{l}\text { Ziman hantu } \\
\text { Jaringao } \\
\text { Brotowali }\end{array}$ & $\begin{array}{l}\text { Atalantia monophyta } \\
\text { Acorus calanuas } \\
\text { Tinospora } \\
\text { tukerculata }\end{array}$ & $\begin{array}{l}\text { Kecubung } \\
\text { Kinjan }\end{array}$ & $\begin{array}{l}\text { Datura fastuosa } \\
\text { Premna paratica }\end{array}$ \\
\hline
\end{tabular}


adalah Inpari 13, 18, 19, 22, 23, 31, dan 33 (Mejana, dkk., 2014).

Tumbuhan-tumbuhan

potensial sebagai pestisida nabati terlihat dalam Tabel 3. Pengelolaan rantai ketersediaan (supply chain management) dari bahan baku tumbuh-tumbuhan tersebut perlu diperhatikan untuk menyediakan bahan baku pestisida nabati yang cukup dan berkesinambungan (Fagi, dkk., 2013). Pemberian pestisida nabati dari biji mimba secara rutin sebagai upaya preventif dapat mengurangi serangan wereng coklat di lahan sawah tadah hujan Pantura Jawa Tengah bagian timur dan menyelamatkan kehilangan hasil sebesar 23,55 persen. Biji mimba selain dimanfaatkan sebagai pestisida nabati (Zakiah, 2017) juga dapat digunakan dalam mitigasi emisi gas $\mathrm{N}_{2} \mathrm{O}$ dan memperbaiki efisiensi penggunaan pupuk nitrogen (Wihardjaka, 2017).

\section{KESIMPULAN}

Inovasi teknologi budidaya tanaman pangan ramah lingkungan yang berkelanjutan secara sosial harus dapat menjamin keberlanjutan pertanian mendatang dan diterima pengguna terutama para petani, serta secara ekonomi dapat memperbaiki kesejahteraan petani. Sistem pertanian tanaman pangan ramah lingkungan secara rasional harus dapat menyejahterakan petani dan keluarganya melalui perbaikan produktivitas tanaman pertanian dan pendapatan sekaligus memperbaiki kualitas lingkungan.

Upaya peningkatan produktivitas
tanaman pangan harus selalu memperhatikan kelestarian lingkungan. Penerapan pertanian ramah lingkungan menjamin stabilitas hasil gabah dan memberikan andil terhadap mitigasi emisi gas rumah kaca di subsektor tanaman pangan.

Penerapan budidaya tanaman pangan ramah lingkungan pada prinsipnya menghindari eksploitasi sumberdaya alam dan penggunaan masukan sarana produksi secara bijaksana (terutama bahan agrokimia seperti pupuk anorganik dan pestisida). Penerapan model pertanian ramah lingkungan untuk tanaman pangan yang mengintegrasikan komponen teknologi spesifik lokasi menjadi efektif dengan melibatkan peran penyuluh dan partisipasi aktif petani baik pada skala petak percontohan, demfarm, dan hamparan.

Beberapa komponen teknologi dalam sistem pertanian ramah lingkungan mampu memberikan hasil tanaman tinggi, emisi gas rumah kaca rendah, dan rendah kontaminan, antara lain pengairan berselang, penggunaan bahan organik matang (nisbah $\mathrm{C} / \mathrm{N}$ rendah) dengan bantuan biodekomposer, pemupukan berimbang, pengendalian hama secara terpadu dengan mengandalkan pestisida nabati, jarak tanam legowo, dan varietas padi unggul rendah emisi.

\section{DAFTAR PUSTAKA}

Abdulrachman, S. 2011. Peranan pendekatan teknologi dan input produksi terhadap produktivitas dan mutu hasil padi. Pangan 20(4): 415-424.

Asnawi, R. 2014. Peningkatan produktivitas dan pendapatan petani melalui penerapan model pengelolaan tanaman terpadu padi sawah di Kabupaten Pesawaran, Lampung. Jurnal Penelitian Pertanian Terapan 14(1): 44-52.

Balitbangtan. 2007. Pengelolaan Tanaman Terpadu Padi Sawah Irigasi. Badan Penelitian dan Pengembangan Pertanian. Jakarta.

Balitbangtan. 2016. Petunjuk Teknis Budidaya Padi Jajar Legowo Super. Badan Penelitian dan Pengembangan Pertanian. Jakarta.

Ditjen Tanaman Pangan. 2014. Pedoman Teknis Sekolah Lapangan Pengelolaan Tanaman Terpadu (SL-PTT) Padi dan Jagung Tahun 2014. Direktorat Jenderal Tanaman Pangan, Kementerian Pertanian.

Doran, J.W., dan T.B. Parkin. 1999. Quantitative indicators of soil quality: A minimum data set. Soil Science Society of America Inc. Winconsin.

Fagi, A.M., A. Djulin, P. Setyanto, dan A. Wihardjaka. 2013. Pedoman Umum Pengembangan Model Pertanian Ramah Lingkungan Berkelanjutan. Edisi Kesatu. Badan Penelitian dan Pengembangan Pertanian. Jakarta.

Gunarto, L., P. Lestari, H. Supadmo, dan A.R. Marzuki. 2002. Dekomposisi jerami padi, inokulasi Azospirillum dan pengaruhnya 
terhadap efisiensi penggunaan pupuk $\mathrm{N}$ pada padi sawah. Penelitian Pertanian Tanaman Pangan 21(1): 1-10.

Harsanti, E.S., S.Y. Jatmiko, dan A.N. Ardiwinata. 2009. Mitigasi residu organofosfat pada lahan bawang merah. Prosiding Seminar Nasional dan Dialog Sumberdaya Lahan Pertanian. Buku III, Informasi Sumberdaya Air, Iklim dan Lingkungan. Bogor, 18-20 November 2008. HIm. 189-200.

Hendrawati, T. 2001. Pengelolaan lahan sawah tadah hujan berwawasan lingkungan. Prosiding Seminar Nasional Budidaya Tanaman Pangan Berwawasan Lingkungan. Jakenan, 7 Maret 2000. Pusat Penelitian dan Pengembangan Tanaman Pangan. Bogor. HIm. 21-35.

Humaedah, U. 2017. Inovasi teknologi menggapai swasembada kedelai. Sinar Tani Edisi 16-22 Agustus 2017. HIm. 3.

Indratin, Poniman, A. Ichwan, dan A.N. Ardiwinata. 2009. Kontaminasi residu organoklorin pada darah petani sayuran di Pati, Magelang, dan Brebes. Prosiding Seminar Nasional dan Dialog Sumberdaya Lahan Pertanian. Buku III, Informasi Sumberdaya Air, Iklim dan Lingkungan. Bogor, 18-20 November 2008. HIm. 113-122.

Kementerian Pertanian. 2015. Rencana Strategis Kementerian Pertanian Tahun 2015-2019. Kementerian Pertanian. Jakarta.

Kurnia, A., S. Wahyuni, dan A.N. Ardiwinata. 2009. Residu organofosfat di lahan pertanian Jawa Tengah. Prosiding Seminar Nasional dan Dialog Sumberdaya Lahan Pertanian. Buku III, Informasi Sumberdaya Air, Iklim dan Lingkungan. Bogor, 18-20 November 2008. Hlm. 181-188.

Mejana, M.J., R.H. Praptana, N.A. Subekti, M. Aqil, A. Musaddad, dan F. Putri. 2014. Deskripsi Varietas Unggul Tanaman Pangan 2009-2014. Pusat Penelitian dan Pengembangan Tanaman Pangan. Bogor.

Republika. 2016. Jajar legowo super dikembangkan ke 11 provinsi. Republika edisi $\quad 18 \quad$ April 2016. http://nasional.republika.co.id/berita/nasio nal/umum/16/04/18/jajar-legowo-superdikembangkan-ke-11-provinsi

Rola, A.C., and P.L. Pingali. 1993. Pesticides, Rice Productivity, and Farmers' Health: An
Economic Assessment. International Rice Research Institute-World Resources Institute. Manila, Washington.

Sembiring, H., dan D. Kusdiaman. 2008. Inovasi teknologi padi mendukung usahatani tanaman-ternak. Dalam: Widjono, A., Hermanto, Sunihardi (eds.). Sistem Integrasi Tanaman Pangan-Ternak Bebas Limbah. Pusat Penelitian dan Pengembangan Tanaman Pangan. Bogor. HIm. 74-85.

Setyanto, P. 2006. Varietas padi rendah emisi gas rumah kaca. Warta Penelitian dan Pengembangan Pertanian 28(4): 12-13.

Setyanto, P., dan R. Kartikawati. 2008. Sistem pengelolaan tanaman padi rendah emisi gas metan. Jurnal Penelitian Pertanian Tanaman Pangan 27(3): 154-163.

Sinar Tani. 2017. Jarwo super menyulap Merauke jadi lumbung pangan. Sinar Tani edisi Rabu, 22 Februari 2017. http:// http://tabloidsinartani.com/content/read/ja rwo-super-menyulap-merauke-jadilumbung-pangan/

Soejitno, J. 2002. Pesticide residues on food crops and vegetables in Indonesia. Jurnal Litbang Pertanian 21(4): 124-132.

Soemarno. 2001. Konsep usahatani lestari dan ramah lingkungan. Prosiding Seminar Nasional Budidaya Tanaman Pangan Berwawasan Lingkungan. Jakenan, 7 Maret 2000. Pusat Penelitian dan Pengembangan Tanaman Pangan. Bogor. HIm. 1-3.

Sulaeman, E., dan A.N. Ardiwinata. 2009. Residu insektisida organoklorin pada tanah dan air sawah di provinsi Jawa Barat. Prosiding Seminar Nasional dan Dialog Sumberdaya Lahan Pertanian. Buku III, Informasi Sumberdaya Air, Iklim dan Lingkungan. Bogor, 18-20 November 2008. HIm. 209-216.

Wihardjaka, A. 2011. Pengaruh sistem tanam dan pemberian jerami padi terhadap emisi metana dan hasil padi Ciherang di ekosistem sawah tadah hujan. Pangan 20(4): 357-364.

Wihardjaka, A. 2017. Biji mimba turunkan emisi dinitrogen oksida dari tanah sawah tadah hujan. Warta Litbang Pertanian 39(3): 57.

Wihardjaka, A., Mulyadi, dan P. Setyanto. 2013. Pendekatan pertanian ramah lingkungan berkelanjutan melalui sistem integrasi tanaman-ternak. Prosiding Ekspose dan Seminar Nasional Akselerasi Inovasi

Penerapan Model Pertanian Ramah Lingkungan sebagai Jaminan Perbaikan Kuantitas dan Kualitas Hasil 
Pertanian Ramah Lingkungan. Makassar, 19-21 Juni 2013:653-663.

Untung, K. 2000. Pelembagaan konsep pengendalian hama terpadu di Indonesia. Jurnal Perlindungan Tanaman Indonesia 6(1): 1-8.

Zakiah. 2017. Potensi mimba (Azadirachta indica $\mathrm{A}$. Juss) sebagai pestisida nabati. Warta Litbang Pertanian 39(2): 9-11.

\begin{tabular}{|l|}
\hline BIODATA : \\
Anicetus Wihardjaka dilahirkan di Padang \\
Panjang tanggal 17 April 1964. Penulis \\
menyelesaikan S1 dari Fakultas Pertanian \\
Universitas Gadjah Mada Yogyakarta tahun \\
1990, S2 dari Fakultas Pertanian Institut \\
Pertanian Bogor tahun 2001, dan S3 dari \\
Sekolah Pasca Sarjana Program Studi IImu \\
Lingkungan Universitas Gadjah Mada tahun \\
2011. \\
\hline
\end{tabular}

